\title{
Nutrient Removal from the Effluent of Swine Slaughterhouse Wastewater by Chlorella vulgaris TISTR 8580
}

\author{
P. Kitrungloadjanaporn, G. Sripongpun, and W. Triampo
}

\begin{abstract}
Chlorella vulgaris TISTR8580 was investigated for its ability to remove nutrient from the effluent of swine slaughterhouse wastewater which was diluted in three different proportions (namely, $75 \%, 50 \%$ and $25 \%$ ). On day 4, which was the end of the batch experiment with 3,000 lux daylight fluorescent lamp, light/dark photoperiod of $12 \mathrm{hr}: 12 \mathrm{hr}$, at $28 \pm 2{ }^{\circ} \mathrm{C}$, it was found that the alga cultured in the $25 \%$ effluent wastewater exhibited the highest growth production with the cell density of $8.51 \pm 2.77 \times 10^{6}$ cells $/ \mathrm{ml}$. However, considering generally not only the nutrient removal efficiency but also the net lipid production, the algae cultured in the $\mathbf{5 0 \%}$ effluent wastewater indicated the best results, i.e. $28.69 \%$ nitrate removal, $28.75 \%$ total phosphorus removal, $15.2 \mathrm{mg} / \mathrm{L}$ lipid weight production, and $\mathbf{2 0 . 9 \%}$ lipid content. Therefore, Chlorella vulgaris can potentially be applied as an alternative for nutrient removal from swine slaughterhouse effluent wastewater as well as biofuel production.
\end{abstract}

Keywords-Chlorella vulgaris, Biofuel, Nutrient removal, Swine slaughterhouse effluent wastewater

\section{INTRODUCTION}

About 18.15 kiloton of pork products was produced in Thailand in the year 2015 [1]. Swine slaughterhouse generates a large volume of wastewater composting of high organic load and nutrient [2], [3]. For example, $1.6-8.3 \mathrm{~m}^{3}$ of water per tonne of carcase is generated in swine slaughterhouse [4]. However, some anaerobic reactors effluents do not meet the standards of the legislation and a post-treatment process to improve the removal of organic matter, nitrogen and phosphorus is required as reported in [5]. Nitrogen and phosphorus without treatment may cause eutrophication in river, lake, sea, upset the balance of the ecosystem and other negative effects such as algal bloom, low dissolved oxygen concentration, fish kill, undesirable $\mathrm{pH}$ shifts and cyanotoxin production. Nutrient removal by chemical and physical treatment can be costly for energy and chemical consumption [6]-[7]. While cultivation of alga in wastewater is considered a potential option for sustainable production of algal biomass by

Manuscript received Nov. 1, 2016. This work was supported in part by the Thailand Center of Excellence in Physics (Thep)

P. Kitrungloadjanaporn is with the Department of Environmental Science, Faculty of Science, Silpakorn University, Nakhon Pathom, Thailand, 73000

G. Sripongpun is with the Department of Environmental Science, Faculty of Science, Silpakorn University, Nakhon Pathom, Thailand, 73000

W. Triampo is with the Department of Physic, Faculty of Science, Mahidol University, Nakhon Pathom, Thailand, 73000 not only reduction in the production cost but also wastewater cleaning by environmental friendly method [8]. Microalgae could grow in different types of wastewaters, such as septage effluent, cattle slaughterhouse, poultry manure and primary piggery wastewater [9]-[14].

The objectives of this study were to assess growth, nutrient uptake and lipid production of Chlorella vulgaris TISTR 8580 from the effluent of swine slaughterhouse wastewater which was diluted in three proportions at 25, 50 and $75 \%$ under experimental condition which has not been published in previous studies. These experiments were performed in order to investigate the potentiality of Chlorella vulgaris TISTR 8580 as an option for nutrient removal and biofuel production from the effluent of swine slaughterhouse wastewater.

\section{MATERIALS AND METHODS}

\section{A. Microalgal Strain and Culture Medium}

The microalgal strain of Chlorella vulgaris TISTR 8580 used in this study was purchased from Thailand Institute of Scientific and Technological Research. Then, it was purified by isolation techniques on Tris-Acetate-Phosphate (TAP) agar [15]. The algal stock was kept in TAP agar slant under 3,000 lux daylight fluorescent lamp, light/dark photoperiod of 12 $\mathrm{hr}: 12 \mathrm{hr}$, at $28 \pm 2^{\circ} \mathrm{C}$ and it was subcultured every two weeks.

The TAP medium was used immediately after preparation for next experiments.

\section{B. The Effluent of Swine Slaughterhouse Wastewater}

The effluent of swine slaughterhouse wastewater was collected after anaerobic digestion from Samphran slaughterhouse Limited Company in Nakhon Pathom, Thailand. In order to make it more practical and related to the real application in the field as well as according to the more efficiency from effluent wastewater without filtration which was recorded in previous study [16], the effluent was used as it was without filtration and its nutrient concentration was shown as in Table I. For further experiments, it was diluted with distilled water (DW) to obtain three different proportions, viz. 25,50 and $75 \%$.

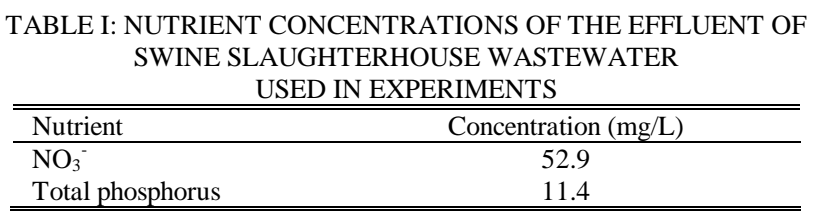




\section{Growth of C. vulgaris TISTR8580 in the Effluent of Swine Slaughterhouse Wastewater}

Starter cultures of C. vulgaris TISTR8580 were prepared by transferring algal colonies on TAP agar slant into $800 \mathrm{ml}$ of TAP medium in $1,000 \mathrm{ml}$ sterilized glass bottles. They were incubated under 3,000 lux daylight fluorescent lamp, light/dark photoperiod of $12 \mathrm{hr}: 12 \mathrm{hr}$, at $28 \pm 2^{\circ} \mathrm{C}$ and continuously aerated with filtered air at the rate of $0.4 \mathrm{vvm}$ (volume of air per volume of culture per minute). Cell density was counted daily by haemacytometer until log phase of the growth curve was obtained with the cell density of $6,350 \times 10^{4}$ cell $/ \mathrm{ml}$. Then, the algae was separated from $80 \mathrm{ml}$ of the starter culture by centrifugation at 3,000 rpm for 15 minutes and it was inoculated into each test bottle containing $800 \mathrm{ml}$ of the selected dilution of the effluent of swine slaughterhouse wastewater for treatment experiments or TAP medium. There were 3 sets of treatment experiments, viz. wc25, wc50 and wc75 which were treatment experiments with test algae in the effluent of swine slaughterhouse wastewater which were diluted in three proportions of 25,50 and $75 \%$, respectively. Batch experiments were performed under the same condition as starter cultures with two replications. All experiments were stopped when algal growth of at least an experiment was in stationary phase because it was reported that the highest lipid content was obtained at the stationary phase of algal growth [17]. Algal growth was monitored by cell counts daily with haemacytometer, then cell density was calculated. Cell size of test algae was also measured by using compound microscope at magnification of 40x with Image Analyzer software. Cell density and cell size of the algae in all test experiments (wc25, wc50, wc75 and TAP medium) were compared.

\section{Nutrient Removal Efficiency from the Effluent of Swine Slaughterhouse Wastewater by C. vulgaris TISTR8580}

Batch experiments were conducted as explained in section C. The initial and final concentration of $\mathrm{NO}_{3}{ }^{-}$and total phosphorus in test swine slaughterhouse wastewater for every dilution of treatment experiments were analyzed by electrode method and persulfate method, respectively, with duplications.

\section{E. Lipid content}

At the end of each experiment, the algal cells were harvested by centrifugation at $8,500 \mathrm{rpm}$ for $5 \mathrm{~min}$. Then, the pellets were freeze-dried and stored at $-20^{\circ} \mathrm{C}$ before analysis. Total lipids were determined by the method of Bligh and Dyer [18]

The lipid content of the microalgae was calculated from the equation:

Lipid content $(\%)=\frac{\text { Weight of extracted lipid }}{\text { Weight of dry biomass }} \times 100$

\section{RESULTS AND DISCUSSION}

\section{A. The Growth of C. vulgaris TISTR8580}

Algal growth can be divided into four different stages, namely (1) lag phase, (2) log phase, (3) stationary phase, and
(4) death phase [19]. The results of this study follow this growth curve and were expressed in Fig.1- Fig.2

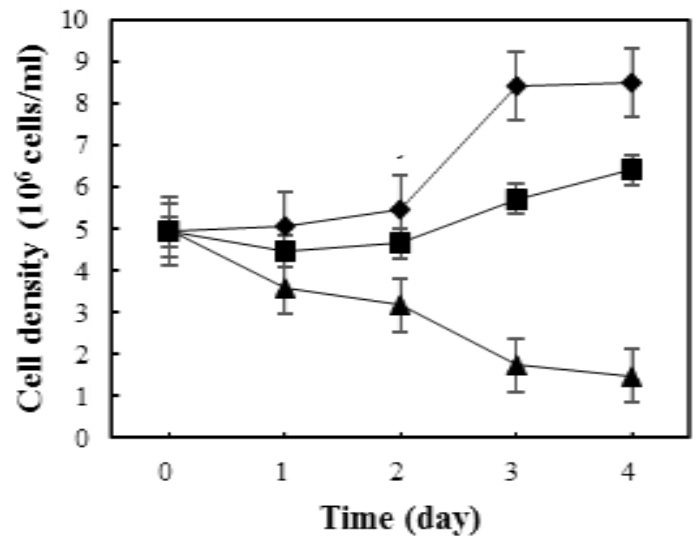

Fig. 1. Cells density of $C$. vulgaris TISTR 8580 cultivated in the effluent of swine slaughterhouse wastewater at the dilution of - 25\% (wc25), $\mathbf{\square}$ 50 (wc50) and $\mathbf{\Delta} 75 \%$ (wc75)

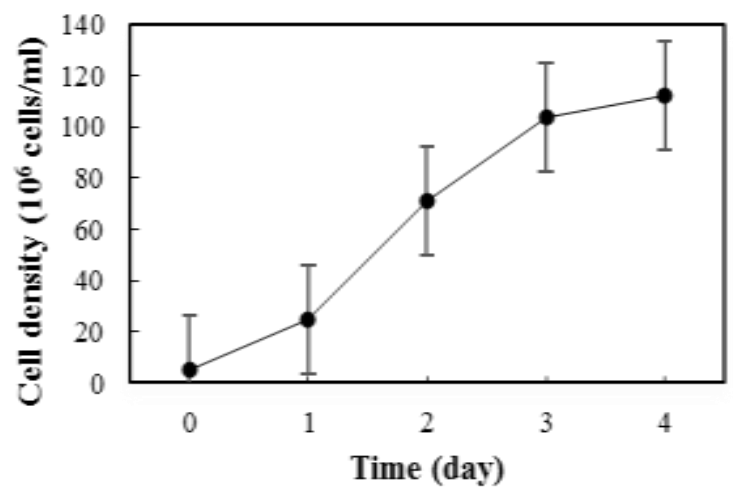

Fig. 2. Cells density of $C$. vulgaris TISTR 8580 cultivated in - TAP medium

From Fig. 1 and Fig. 2, within 4 days the alga cultured in TAP medium and in $25 \%$ of the effluent wastewater (wc25) grew up to stationary phase while those in $50 \%$ of the effluent wastewater (wc50) were still in log phase. In the case of alga cultured in $75 \%$ of the effluent wastewater (wc75) did not resemble the normal growth of algae but they were in declining stage which were indicated by the decreasing line in Fig. 1. In addition, the change of their cell size was relatively the least and was different from those in others [Fig.3]. This was in accordance with the observation of changing of algal color from green to slightly yellow color in wc75 treatment experiment. This result agreed with the study of Wrigley and Toerien [20] which reported that wastewater often had high concentration of nutrients and much of the nitrogen in the form of $\mathrm{NH}_{4}-\mathrm{N}$ could inhibit algal growth at high concentration. The lag phase of the alga cultured in TAP medium occurred probably $>1$ day, log phase from 1 day (or probably > 1 day) to 3 days, stationary phase from 3 to 4 days (the final day of the experiment). For treatment experiments, wc25 experiment exhibited the highest growth production with the cell density of $8.51 \pm 2.77 \times 10^{6}$ cells $/ \mathrm{ml}$ at the end of 
the experiment, however, it is approximately 13 time less than that in TAP medium (the rich medium for the algal growth). The results in this study were in consistent with the result of Rowley [21] who suggested that the N:P ratio should be at least 3:1 in order to maximize $C$. vulgaris growth. Because the $\mathrm{N}: \mathrm{P}$ ratios for $\mathrm{wc} 25$ and $\mathrm{wc} 50$ in this study are 2.69 and 2.20 , respectively. Therefore, the ratio for wc 25 is close to the suggested ratio more than that for wc50 resulted in higher growth as expressed in the term of cell density [Fig. 1]. For wc25 and wc50 treatment experiments, the lag phase occurred the same period of time (between 0 and 2 days). But the further periods of their growth curve were different. For wc25 experiment, log phase occurred from 2 to 3 days and stationary phase from 3 to 4 days but for wc50 experiment the log growth phase was continued until the end of the experiment (4 days) and has not reach the stationary and declining phases yet.

Cells size of microalgae in TAP medium had smaller size than wc25, wc50 and wc75. This should be because Tap medium was more suitable medium for algal growth than other treatment experiment, therefore, TAP medium can support algal cell division more than others [Fig. 3].

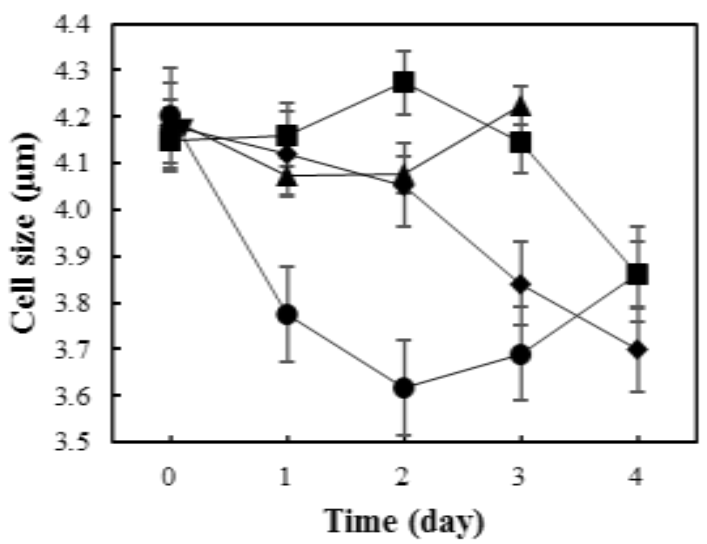

Fig. 3. Cells size of $C$. vulgaris TISTR 8580 cultivated in ๑TAP medium and in the effluent of swine slaughterhouse wastewater at the dilution of $25 \%$ (wc25), $\mathbf{\square}$ 50\% (wc50) and $\mathbf{\Delta} 75 \%$ (wc75)

B. Removal of nitrate and total phosphorus from the effluent of swine slaughterhouse wastewater

Nitrate and total phosphorus can be removed from wastewater by their uptake to microalgal cells. The living cells drew nitrate and phosphorus in the surrounding environment for syntheses of amino acids, pigment, nucleic acids, ATP, biochemical precursors, etc. Limitation of these nutrients would lead to retardation in growth, metabolic efficiency and ultimately survival in the environment [22]. In addition, the majority of dissolved inorganic nitrogen in effluent wastewater was in the form of $\mathrm{NO}_{\mathrm{x}}-\mathrm{N}$ and it was reported that the majority of nitrogen in the form of $\mathrm{NO}_{\mathrm{x}}-\mathrm{N}$ was removed in effluent wastewater [23]. Moreover, nitrate is a commonly studied $\mathrm{N}$ source for understanding nutrient deprivation to induce lipid accumulation [24], therefore nitrate and total phosphorus were chosen as the representative for $\mathrm{N}$ and $\mathrm{P}$ sources in effluent wastewater in the present study.

The results for nitrate and total phosphorus removal from the effluent of swine slaughterhouse wastewater by $C$. vulgaris were expressed in Table II. The best results for nitrate and total phosphorus removal were achieved in wc25 and wc75 treatment experiments with the values of $53.06 \%$ and $32.35 \%$, respectively. While considering for both nitrate and total phosphorus in general, wc50 treatment experiment may provide better result. However, these were lower than the results for $\mathrm{NO}_{\mathrm{x}}-\mathrm{N}$ and total phosphorus removal efficiency from municipal wastewater by $C$. vulgaris which were reported at more than $88 \%$ and $90 \%$, respectively [23]. This might be due to different in many parameters such as effluent preparation, culturing condition, and incubation time.

TABLE II: THE REMOVAL OF NITRATE AND TOTAL PHOSPHORUS FROM THE EFFLUENT OF SWINE SLAUGHTERHOUSE WASTEWATER

\begin{tabular}{ccccc}
\hline \hline Nutrient & Treatment & $\begin{array}{c}\text { Initial } \\
\text { concentration } \\
(\mathrm{mg} / \mathrm{L})\end{array}$ & $\begin{array}{c}\text { Final } \\
\text { concentration } \\
(\mathrm{mg} / \mathrm{L})\end{array}$ & $\begin{array}{c}\text { Removal } \\
(\%)\end{array}$ \\
\hline $\mathrm{NO}_{3}{ }^{-}$ & wc25 & $12.25 \pm 0.78$ & $5.75 \pm 0.07$ & 53.06 \\
$(\mathrm{mg} / \mathrm{L})$ & wc50 & $17.60 \pm 0.28$ & $12.55 \pm 0.07$ & 28.69 \\
& wc75 & $40.45 \pm 0.35$ & $39.95 \pm 0.07$ & 1.24 \\
$\mathrm{TP}$ & wc25 & $4.55 \pm 0.07$ & $3.75 \pm 0.07$ & 17.58 \\
$(\mathrm{mg} / \mathrm{L})$ & wc50 & $8.00 \pm 0.00$ & $5.70 \pm 0.00$ & 28.75 \\
& wc75 & $10.20 \pm 0.28$ & $6.80 \pm 0.00$ & 32.35 \\
\hline \hline
\end{tabular}

\section{Lipid content}

The lipid content of test microalgae was calculated by equation 1 and the results were expressed in Table III. All lipid content from treatment experiments (wc25, wc50 and wc75) were higher than that from TAP medium, this might be as a result of changing from rich medium to effluent wastewater in treatment experiments may cause stress to the algae. Because previous research [25] concluded that lipid content of C. vulgaris increased from $20 \%$ to $43 \%$ of dry weight under nitrogen starvation conditions. On the contrary, dry cell weight, and lipid weight of the alga from TAP medium were higher than those from the treatment experiments. Among these treatment experiments, wc50 exhibited the best for net lipid production [Table III].

TABLE III: DRY CELL WEIGHT, LIPID WEIGHT AND LIPID CONTENT OF CHLORELLA VULGARIS TISTR 8580

\begin{tabular}{cccc}
\hline \hline Experiment & $\begin{array}{c}\text { Dry cell weight } \\
(\mathrm{mg})\end{array}$ & $\begin{array}{c}\text { Lipid weight } \\
(\mathrm{mg})\end{array}$ & Lipid content $(\%)$ \\
\hline TAP & $393.50 \pm 75.57$ & $65.24 \pm 1.67$ & $16.58 \pm 0.00$ \\
wc25 & $52.66 \pm 1.15$ & $9.34 \pm 0.13$ & $17.73 \pm 0.00$ \\
wc50 & $58.22 \pm 4.72$ & $12.16 \pm 2.37$ & $20.90 \pm 0.00$ \\
wc75 & $46.97 \pm 6.05$ & $10.76 \pm 0.07$ & $22.91 \pm 0.00$ \\
\hline \hline
\end{tabular}

\section{CONCLUSION}

In this study, Chlorella vulgaris TISTR8580 was used to remove nutrient in the effluent of swine slaughterhouse 
wastewater. The results indicated that $C$. vulgaris TISTR8580 grew only in wc25 and wc50 experiments. However, the alga in wc25 provided the best growth. The best removal efficiencies for nitrate and total phosphorus were obtained from wc25 and wc75 experiment, respectively. Nevertheless, wc50 experiment showed good results considering for both nitrate and total phosphorus removal. The alga in wc75 experiment resulted in the highest lipid content but the alga in wc50 experiment could provide the best net lipid production. Then, C. vulgaris culture in the effluent of swine slaughterhouse wastewater can be an alternative for nutrient removal and biofuel production.

\section{ACKNOWLEDGMENT}

This research project is supported in part by Thailand Center of Excellence in Physics (Thep) and Centre of Excellence in Mathematics, PERDO, CHE, Thailand. The authors would like to express their gratitude to Dr. G. Sripongpun, Dr. W. Triampo , and Dr. S. Amornsamankul for their kind encouragement and advice throughout this study. The authors also thank to N. Nuttavut for his support.

\section{REFERENCES}

[1] Office of Agricultural Economics. (December 2015). Agricultural economic outlook. [Online]. Available:

http://www.oae.go.th/download/document_tendency/58-59/0.pdf

[2] G. S. Mittal, "Treatment of wastewater from abattoirs before land application: a review," Bioresour. Technol., vol. 97, pp. 1119- 1135, Jun. 2006.

https://doi.org/10.1016/j.biortech.2004.11.021

[3] C. Bustillo-Lecompte1, M. Mehrvar, and E. Quiñones-Bolaños. "Slaughterhouse wastewater characterization and treatment: An economic and public health necessity of the meat processing industry in Ontario, Canada," J. Geosci. and Environ. Protect., vol. 4, pp. 175-186, Apr. 2016. https://doi.org/10.4236/gep.2016.44021

[4] J. P. Li, M.G. Healy, X.M. Zhan, and M. Rodgers, "Nutrient removal from slaughterhouse wastewater in an intermittently aerated sequencing batch reactor," Bioresour. Technol., vol. 99, pp. 7644-7650, Mar. 2008. https://doi.org/10.1016/j.biortech.2008.02.001

[5] I.R. de Nardi, V. Del Nery, A.K.B. Amorim, N.G. dos Santos, and F. Chimenes, "Performances of SBR, chemical-DAF and UV disinfection for poultry slaughterhouse wastewater reclamation." Desalination, vol. 269, pp. 184-189, Mar. 2011. https://doi.org/10.1016/j.desal.2010.10.060

[6] T. Cail, S. Y. Park, and Y. Li, "Nutrient recovery from wastewater streams by microalgae: Status and prospects," Renew. Sust. Energ. Rev., vol. 19, pp. 360-369, Mar. 2013. https://doi.org/10.1016/j.rser.2012.11.030

[7] L. Christenson, and R. Sims, "Production and harvesting of microalgae for wastewater treatment, biofuels, and bioproducts," Biotechnol. Adv., vol. 29, pp. 686-702, Nov.-Dec. 2011. https://doi.org/10.1016/j.biotechadv.2011.05.015

[8] N. H. Norsker, M. J. Barbosa, M. H. Vermuë, and R. H. Wijffels, "Microalgal production - A close look at the economics," Biotechnol. Adv., vol. 29, pp. 21-24, Jan.-Feb. 2011. https://doi.org/10.1016/j.biotechadv.2010.08.005

[9] S. Sreesai, and P. Pakpain, "Nutrient recycling by Chlorella vulgaris from septage effluent of the Bangkok city, Thailand," Science Asia, vol. 33, pp. 293-299, Apr. 2007.

https://doi.org/10.2306/scienceasia1513-1874.2007.33.2 93

[10] M. M. Maronezel, J. S. Barin1, C. R. de Menezes, M. I. Queiroz, L. Q. Zepkal, and E. Jacob-Lopes, "Treatment of cattle-slaughterhouse wastewater and the reuse of sludge for biodiesel production by microalgal heterotrophic bioreactors," Sci. Agric., vol. 71, pp. 521-524, May 2014. https://doi.org/10.1590/0103-9016-2014-0092

[11] S. Lima, W.. Chub, and S. Phang, "Use of Chlorella vulgaris for bioremediation of textile wastewater," Bioresour. Technol., vol. 101, pp. 7314-7322, Oct. 2010. https://doi.org/10.1016/j.biortech.2010.04.092

[12] Y. Zhang, D. Su, G. Zhang, J. Li, S. Hu, S. Han, L. Zeng, and T. Chen, "Use of Chlorella for the treatment of the soft-shelled turtle processing wastewater," Adv. J. Food Sci. Technol., vol. 5, pp. 1573-1576, Dec. 2013.

[13] G. D. Iyovo, G. Du, and J. Chen, "Poultry manure digestate enhancement of Chlorella vulgaris biomass under mixotrophic condition for biofuel production," J. Microb. Biochem. Technol., vol. 5, pp. 1573-1576, Dec. 2013.

[14] H. Wang, H. Xiong, Z. Hui, and X. Zeng, "Mixotrophic cultivation of Chlorella pyrenoidosa with diluted primary piggery wastewater to produce lipids," Bioresour. Technol., vol. 104, pp. 215-220, Jan. 2012. https://doi.org/10.1016/j.biortech.2011.11.020

[15] L. Wang, M. Min, Y. Li, P. Chen, Y. Chen, Y. Liu, Yi. Wang, and R. Ruan, "Cultivation of green algae Chlorella sp. in different wastewaters from municipal wastewater treatment plant," Appl. Biochem. Biotechnol., vol. 162, pp. 1174-1186, Oct. 2010. https://doi.org/10.1007/s12010-009-8866-7

[16] B. Kumsiri and C. Pumas, "Microalgal cultivation with effluent from chicken manure bio-gas plant for lipid production," J. Fish. Technol., vol. 7, pp. 25-34, Oct.2013.

[17] Q. Hu, R. Zeng, S. Zhang, Z. Yang, and H. Huang, "Production of microalgal lipids as biodiesel feedstock with fixation of $\mathrm{CO}_{2}$ by Chlorella vulgaris," Food Technol. Biotechnol., vol. 52, pp. 285-291, Mar. 2014.

[18] E. G. Bligh, and W. J. Dyer, "A rapid method of total lipid extraction and pulification,” Can. J. Biochem. Phys., vol. 37, pp. 911-917, Aug. 1959. https://doi.org/10.1139/o59-099

[19] N. Moazami, A. Ashori, R. Ranjbar, M. Tangestani, R. Eghtesadi, A. S. Nejad, "Large scale biodiesel production using microalgae biomass of Nannochloropsis," Biomass Bioen., vol. 39, pp. 449-453, Apr. 2012. https://doi.org/10.1016/j.biombioe.2012.01.046

[20] T. J. Wrigley and D. F. Toerien, "Limnology aspects of small sewage ponds," Water Res., vol. 24, pp. 83-90. Jan. 1990. https://doi.org/10.1016/0043-1354(90)90068-H

[21] W. M. Rowley. "Nitrogen and phosphorus biomass-kinetic model for Chlorella vulgaris in a biofuel production scheme," M.S. thesis, Dept. Systems and Engineering Management, Graduate School of Engineering and Management, Air Force Institute of Technologt, Air University, Ohio, USA, 2010.

[22] K.C.A. Jalal, M.Z. Alam, W.A. Matin, B.Y. Kamaruzzaman, J. Akbar, and T. Hossain, "Removal of nitrate and phosphate from municipal wastewater sludge by Chlorella vulgaris, Spirulina platensis and Scenedesmus quadricauda,” IIUM Eng. J, vol. 12, pp. 125-132, 2011.

[23] C. Wang, X. Yu, H. Lv and J. Yang, "Nitrogen and phosphorus removal from municipal wastewater by the green alga Chlorella sp.," J. Environ. Biol., vol. 34, pp. 421-425, Apr. 2013.

[24] M. W. Fields, A. Hise, E. J. Lohman, T. Bell, R. D. Gardner, L. Corredor, K. Moll, B. M. Peyton, G. W. Characklis, and R. Gerlach, "Sources and resources: importance of nutrients, resource allocation, and ecology in microalgal cultivation for lipid accumulation,"App. Microbiol. Biotechnol., vol. 98, pp. 4805-4816, Apr. 2014. https://doi.org/10.1007/s00253-014-5694-7

[25] G. Mujtaba, W. Choi, C. Lee, and K. Lee, "Lipid production by Chlorella vulagris after a shift from nutrient-rich to nitrogen starvation conditions," Bioresour. Technol., vol. 123, pp. 279-283, July. 2012.

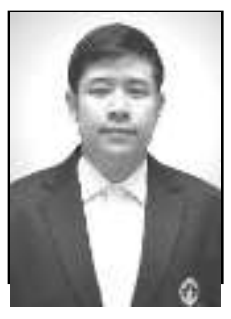

Pongpatai Kitrungloadjanaporn was born in Nakhon Pathom, Thailand, in 1986. He received the B.Sc. degree in animal science from Maejo University, Chaingmai, Thailand in 2009. He is currently a postgraduated student in Department of Environmental Science, Graduate School, Silpakorn University, Nakhon Pathom, Thailand.

$\mathrm{He}$ is currently a scientist at Institute for Innovative Learning, Mahidol University, Nakhon Pathom, Thailand. Example of publications were as follow: "Seesaw Balancing: Moment of force instructional medium science for secondary students," the National Conference Proceeding of Science Education to Inspire Innovation 2014, ed. K. Buaraphan and P. Sudta, pp. 253-255, vol. 1, Thailand: Faculty of Science and Technology, Phetchaburi Rajabath University Press, 2014; and "Optimized experiment methodology for 
studying nano biointeraction: The effect of $\mathrm{TiO}_{2}$ nanoparticles on $E$. coli." The Proceeding of the $37^{\text {th }}$ Congress on Science and Technology of Thailand, ed. S. Chongthammakun, pp. 209-210, vol. 37, Thailand: The Science Society of Thailand under the Patronage of His Majesty the King, 2011. His research interests are algal cultivation and energy.

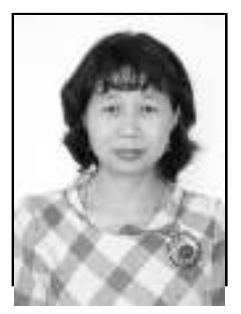

Guntharee Sripongpun was born in Songkhla, Thailand, in 1958. She received the B.Sc. degree in biology from Prince of Songkhla University (PSU), Songkhla, Thailand, in 1979; M.Sc. degree in environmental biology from Mahidol University, Bangkok, Thailand, in 1882; Postgraduate diploma in environmental science and technology (distinction which is fully equivalent to M.Sc.) from International Institute for Hydraulic and Environmental Engineering (IHE), Delft, the Netherlands, in 1986; and Ph. D. degree in environmental science from Griffith University, Brisbane, Australia, in 1996.

From 1982 to now she works as a lecturer in the Department of Environmental Science, Silpakorn University, Nakhon Pathom, Thailand where she teaches courses on water pollution, environmental science, and environmental management. She is an author of two books on water pollution and pesticides in the environment, and as a coauthor of two laboratory manuals on water quality analysis and environmental science. Examples of publications were as follow: "Annual variations of environmental conditions in naturally ventilated classrooms in a tropical environment: Comparison with proposed guidelines," Silpakorn U Science \& Tech J, vol. 10, pp. 37-50, Aug. 2016; "Factors affecting people's participation in household solid waste source sorting in Prong Madua Subdistrict, Muang District, Nakhon Pathom Province," $J$ Public Health, vol. 46, pp.57-70, Jan.-Apr. 2016. Her research interests are waste utilization and water pollution.

Assoc. Prof. Sripongpun was the recipient of the golden pin award for the $1^{\text {st }}$ rank student among the $1^{\text {st }}-4^{\text {th }}$ year B.Sc. student in Biology Department, Faculty of Science, PSU from Thab Neelanithi Foundation in 1980; Thab Neelanithi Foundation scholarship for qualified M.Sc. student during 1981-1983; the Netherland fellowship program for postgraduate diploma in environmental science and technology during 1985-1986; Australian Government under International Development Program of Australian Universities and Colleges for Ph.D. scholarship during 1991-1995; and research funds supported by many organizations, such as National Research Council of Thailand (NRCT), Faculty of Science, Silpakorn University, the Western Region Information Network Project, Thailand Government Annual Budget, and Silpakorn University Income since 1982.

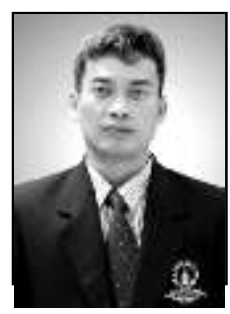

Wannapong Triampo was born in Nakhon Ratchasima, Thailand, in 1970. He received the B.Sc. degree in physics with the 1st class honoured from Mahidol University, Bangkok, Thailand in 1993; M.Sc. degree in applied mathematics from Mahidol University, Bangkok, Thailand in 1995; M.Sc. degree in Physics from Virginia Polytechnic Institute \& State University, USA in 1996; and Ph.D. degree in physics from Virginia Polytechnic Institute \& State University, USA, in 2001.

$\mathrm{He}$ is currently working as an Assoc. Prof. of Physics in Department of Physics, Faculty of Science, Mahidol University, Nakorn Pathom, Thailand. Examples of publications were as follow: "The impact of rainfall and temperature on the spatial progression of cases during the chikungunya re-emergence in Thailand in 2008-2009," T. Roy. Soc. Trop. Med. H., vol.110, pp. 125-133, Jan. 2016.; "Development of a test to evaluate students' analytical thinking based on fact versus opinion differentiation," Int. J. Instr., vol. 9, pp. 123-138, July 2016; "Biophysical approach to investigate temperature effects on protein dynamics," Eur. Phys. J. Appl. Phys., vol. 71, id. 31201, 10 pp., doi:10.1051/epjap/2015150180, Aug. 2015. His research interests are biophysics, nanoscience for environmental research, modelling and computer simulations, and Science and mathematics education.

He had received a reward for top most publication in SCOPUS year 2010 from Mahidol University. 